\title{
Occurence of pectinolytic bacteria causing blackleg and soft rot of potato in Kenya
}

\author{
Jane W. Kamau $^{1}$ (D) Jane Ngaira ${ }^{1} \cdot$ Johnson Kinyua $^{1} \cdot$ Sospeter Gachamba $^{2} \cdot$ George Ngundo $^{2} \cdot$ Jaap Janse $^{3} \cdot$ \\ Isaac Macharia ${ }^{2}$
}

Received: 23 February 2018 / Accepted: 11 December 2018 / Published online: 10 January 2019

(C) The Author(s) 2019

\begin{abstract}
Potato (Solanum tuberosum) is the second most important crop after maize in Kenya and plays a major role in national food production and security. Despite its importance, production is constrained by a number of factors, including diseases. Diseases caused by bacteria are a major biotic production constraint. Soft rot and blackleg diseases are considered as important constraints causing considerable losses in many production systems. However, there is scanty information on soft rot and blackleg in potato production systems in Kenya. A limited survey was conducted between September and October 2016 and in December 2016 to January 2017 in four major potato growing regions to determine the identity of pectinolytic bacteria causing blackleg and soft rot disease of potato in Kenya. Tubers and stems with symptoms of blackleg and soft rot disease were collected from 91 randomly selected farms. Identification of the pathogens was done using phenotypic methods which involved culturing on semi-selective medium, biochemical tests, pathogenicity tests and DNA based methods. The results identified occurrence of Pectobacterium carotovorum subsp. carotovorum (6 isolates) in all four regions and Pectobacterium wasabiae (5 isolates) for the first time in Elgeiyo Marakwet. The identity of twelve isolates could not be specified and therefore needs further investigation.
\end{abstract}

Keywords Pectobacterium · Dickeya $\cdot$ Survey

Kenya is among the top potato producers in Africa where the crop is grown by approximately 500,000 farmers, mainly small-scale farmers, on over 120,000 ha with an average yield of 7.7 tons per hectare (Wang'ombe and Dijk 2013) and plays a major role in national food and nutritional security. However, its production is constrained by a number of factors including bacterial diseases such as brown rot caused by Ralstonia solanacearum, and blackleg and soft rot caused by Pectobacterium and Dickeya spp. (formerly classified as Erwinia spp.) (Czajkowski et al. 2015; Rosenzweig et al. 2016).

Jane W. Kamau

jwanjiku@kephis.org; jynwanjiku83@gmail.com

1 Department of Biochemistry, Jomo Kenyatta University of Agriculture and Technology, Nairobi, Kenya

2 Department of Phytosanitary Services, Kenya Plant Health Inspectorate Service, Nairobi, Kenya

3 Department Laboratory Methods and Diagnostics, Dutch General Inspection Service (NAK), Emmeloord, The Netherlands
In the recent past, Pectobacterium carotovorum subsp. carotovorum and subsp. brasiliense have been reported to cause disease in potatoes in some parts of Kenya (Onkendi et al. 2014) leading to significant losses in potato production. Usually, soft rot are observed as water soaked lesions on tubers, which gradually become soft, mushy, disintegrated, depressed and discoloured (Rahman et al. 2012). The tissue within the affected region becomes black and/or creamy and slimy (Pectobacterium carotovorum spp. (PC) and Dickeya spp.) in colour and gradually becomes disintegrated, forming a mushy mass of disorganized cells. The presence of black rots or lesions spreading from the rotting mother tuber up the stems with black coloration and/or vascular browning are considered typical symptoms for blackleg and (aerial) stem rot.

Other cultivated host plants known to be infected by Pectobacterium and Dickeya spp. and grown in Kenya include: Musa spp., Zea mays, Ipomea batatas, Brassica spp., Capsicum spp., Daucus carota, Alium cepa, Solanum lycopersicum, Ananas comosus, Oryza sativa and Saccharum officinarum (Dickey 1979). These crops could act as a reservoir for inoculum to potatoes. 
Table 1 Isolates used in this study as positive controls

\begin{tabular}{llll}
\hline Strain Name & Strain Number & Source & Origin \\
\hline Erwinia chrysanthemi & PD 97 & Chrysanthemum sp & Netherlands \\
Pectobacterium carotovorum subsp. carotovorum & PD 1006 & Solanum tuberosum & Netherlands \\
Dickeya dianthicola & GBBC 322 & Solanum tuberosum & Belgium \\
Pectobacterium carotovorum subsp. brasilinse & GBBC 1819 & Solanum tuberosum & Belgium \\
Pectobacterium carotovorum subsp. wasabiae & GBBC 1814 & Solanum tuberosum & Belgium \\
\hline
\end{tabular}

Pectinolytic bacteria, under favorable climatic conditions can cause significant yield loss in potato fields. Some of these bacteria may survive in the soil and may decrease yield in subsequent productions of potato in the same field. When volunteer potatoes are not removed the disease situation may be worsened even more (Rosenzweig et al. 2016). Moreover, these phytopathogens may stay latent in the field with a possible high impact on the tuber yield in the upcoming season depending on weather conditions and cultural practices. Detections of latent infections requires sensitive diagnostic methods. As yet, the causal agents for blackleg and soft rot disease of potato in Kenya have not been sufficiently studied. Currently it is not fully known what strains are present in what regions of potato production in Kenya. Research has only recently reported Pectobacterium carotovorum subsp. carotovorum and subsp. brassiliense to be responsible for the disease in Kenya (Onkendi et al. 2014) contributing to potato yield losses both in the field and storages in two regions, Nyandarua and Mau Narok. There is a definite need to investigate which other Pectobacterium and/or Dickeya spp. are responsible for these diseases in other potato production areas in Kenya.

A survey was conducted during the short rain potato growing season that started from September 2016 to January 2017. Samples of plants showing blackleg and potato tubers showing soft rot symptoms were collected for laboratory analysis from four major potato growing regions of Kenya namely Nakuru, Nyandarua, Narok and Elgeiyo Marakwet. A farm was sampled after every $2 \mathrm{~km}$ since many farms were growing potato in the survey regions. Symptomatic plants were sampled at random by moving diagonally across each field.

Samples were prepared and plated on crystal violet polypectate (CVP) medium as described by Helias et al. (2012) and Lee and $\mathrm{Yu}$ (2006) and incubated at $27^{\circ} \mathrm{C}$ for up to $48 \mathrm{~h}$ then checked for presence of pectinolytic colonies. Purification of bacterial colonies was done by re-streaking of a single colony on sterile nutrient agar plates and a suspension of 10.7 cells/ml in phosphate buffer solution $\mathrm{pH} 7.4$ of each isolate was stored at $-20{ }^{\circ} \mathrm{C}$ in $10 \%$ glycerol.

Reference strains used in the study were as outlined in Table 1. The isolates obtained in this study were purified and biochemically analysed according to testing methods described by Perombelon (2002). Tests performed were: oxidative/fermentative metabolism of glucose, oxidase reaction, catalase test with $3 \%$ hydrogen peroxide, reduction of sugars from sucrose, and ability to produce indole from tryptophane

To demonstrate the ability of the bacterial isolates to cause tuber soft rot on potato tuber slices and blackleg symptoms on potato plant, we performed pathogenicity tests as described by Naqqash et al. (2016) and Ismail and Mostafa (2012). Certified seed tubers (shangi) obtained from International Potato Center (CIP), Kenya, were sterilized with $70 \%$ alcohol, rinsed with sterile distilled water and aseptically cut into $1 \mathrm{~cm}$ thick slices. The potato slices were placed in sterile Petri dishes containing sterilized filter paper soaked with $2 \mathrm{ml}$ of sterile distilled water. Tests for soft rot characteristics were done in duplicate. Potato slices were inoculated by spreading a bacterial colony on the surface using a sterile inoculating loop. Inoculated slices were maintained in moist conditions and were incubated at $27^{\circ} \mathrm{C}$ for 5 days. Bacterial cultures that produced characteristic symptoms of soft rot on potato slices were selected and recorded as positive. For blackleg and stem rot test, certified seed tubers with 3-5 buds were sterilized with $70 \%$ alcohol and rinsed with sterile distilled water. Tubers were pricked with a needle to create wounds for infection. The wounded tubers were soaked for $15 \mathrm{~min}$ in bacterial

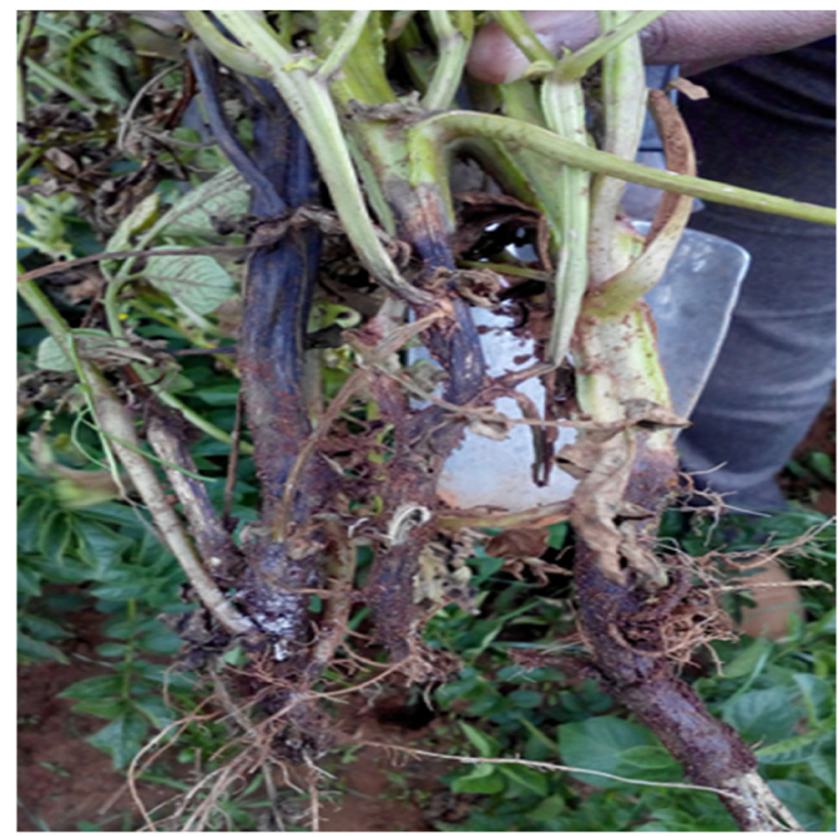

Fig. 1 Blackleg symptoms on stems of potato plants in the fields 


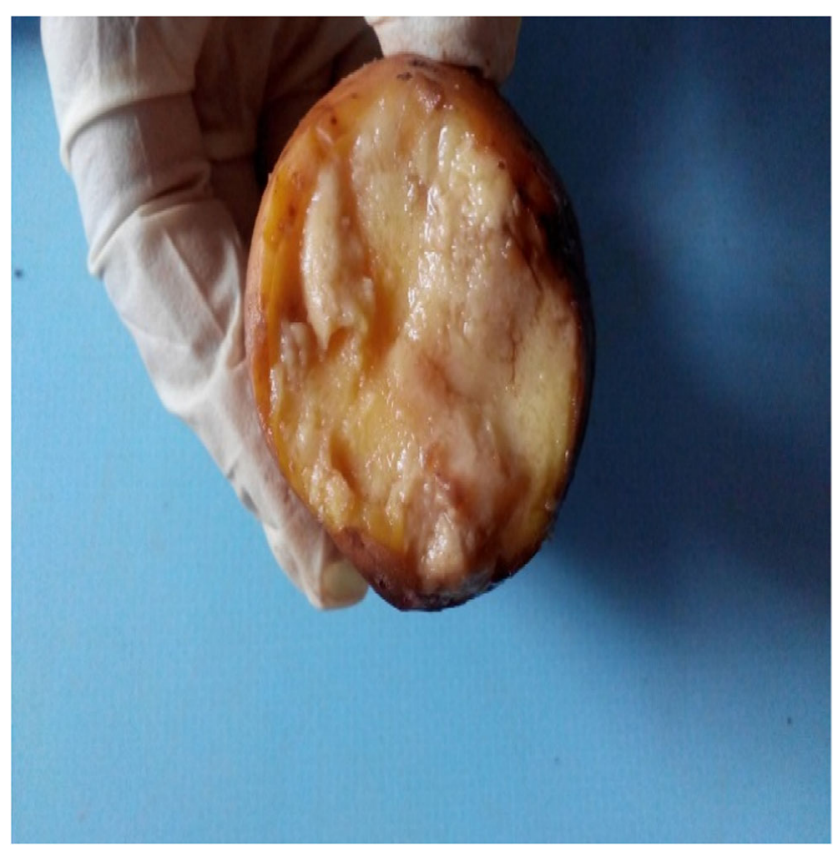

Fig. 2 Soft rot symptoms observed on tubers in potato fields

suspension containing $1 \times 10^{7}$ cells per ml. Inoculated tubers were planted in pots containing sterile soil amended with DiAmmonium Phosphate (Mavuno®) fertilizer under greenhouse conditions maintained at $25-30{ }^{\circ} \mathrm{C}$ for 90 days. Watering of plants in the greenhouse was done for 3 days in a week. Observations were made for blackleg and soft rot symptoms within 21 days.

Genomic DNA was extracted from bacterial cells using a standard DNA extraction method as described by Sambrook and Russell (2001). The DNA quantity and quality was verified in a $0.8 \%$ agarose gel. Amplifications using conventional PCR was done to further identify the isolates which had turned positive by phenotypic methods. Reactions were performed with final concentrations as described by Pritchard et al. (2012) and Kim et al. (2012) with primers for Pectobacterium carotovorum subsp. carotovorum
(EXPCCF/EXPCCR), Pectobacterium wasabiae (PW7011F/ PW7011R) and Dickeya spp. (ADE1/ADE and BRIf /LIr for Pectobacterium carotovorumm subsp. brasiliense 2). Thermal profiles were as described by Pritchard et al. (2012), using an ABI GENE Thermocycler ${ }^{\circledR}$. All primers were sourced from Inqaba Biotech, South Africa. An aliquot of $5 \mu \mathrm{l}$ from the amplified PCR products was stained with GelRed ${ }^{\circledR}$ $(10,000$ units) and the products separated on $1.5 \%(w / v)$ agarose gel in $1 \times$ Tris Borate EDTA buffer. Products were visualized under Gel Doc-It Imaging system ${ }^{\circledR}(800) 452-6788$, Upland-CA, USA. Amplicon sizes were established by comparing to a standard $100 \mathrm{bp}$ molecular ladder (Fermentas ${ }^{\circledR}$ ).

Real time PCR for Dickeya dianthicola was done using primer and probe specific for Dickeya dianthicola (DIA-A F/ DIA-A R DIA-A P) as described by Pritchard et al. (2012). The reaction contained $25 \mathrm{mM} \mathrm{MgCl}_{2}, 10 \mathrm{mM}$ dNTP mix, $5 \mu \mathrm{M}$ forward and reverse primers, $5 \mu \mathrm{M}$ probe, $0.63 \mathrm{U}$ DNA polymerase (AmpliTaq ${ }^{\circledR}$ Gold) and $50 \mathrm{ng} / \mathrm{ul}$ of template. Reaction conditions were set at a denaturation phase of $10 \mathrm{~min}$ at $95^{\circ} \mathrm{C}$ and 40 PCR cycles of $15 \mathrm{~s}$ at $95^{\circ} \mathrm{C}$ followed by $60 \mathrm{~s}$ at $60^{\circ} \mathrm{C}$ (Pritchard et al. 2012) in Realplex Eppendorf AG® (Germany) sequence detector using TaqMan chemistry.

A total of 91 samples were collected in the field, showing typical symptoms of blackleg, tuber soft rot or stem rot (Figs. 1 and 2). Pectinolytic bacteria secrete effective cell wall degrading enzymes (Pritchard et al. 2012), responsible for tissue maceration which usually gives characteristics water soaked, slimy and rotten appearance of the infected plant as well as black colouration from the mother tuber up the stem. Our samples showed these symptoms in the field (Fig. 1) while infected tubers were soft, watery with decayed mass (Fig. 2). Following isolation on CVP, 79 samples produced pit cavities. When these isolates were tested on tubers for pathogenesis, 26 of them showed rotting on potato slices (Fig. 5) and 12 out of the 26 showed blackleg and stem rot symptoms (Fig. 4). Biochemical tests were done to further characterize the isolates and to separate the putative Pectobacterium spp. and the Dickeya spp. The results showed that nine isolates did not produce indole and might belong to the genus
Fig. 3 PCR amplification of Pectobacterium carotovorum subsp.wasabiae; 71, 74, 76, 81, 84 are samples from from Elgeiyo Marakwet. Band sizes compared against $100 \mathrm{bp}$ ladder. The isolates gave the expected size of $140 \mathrm{bp}$

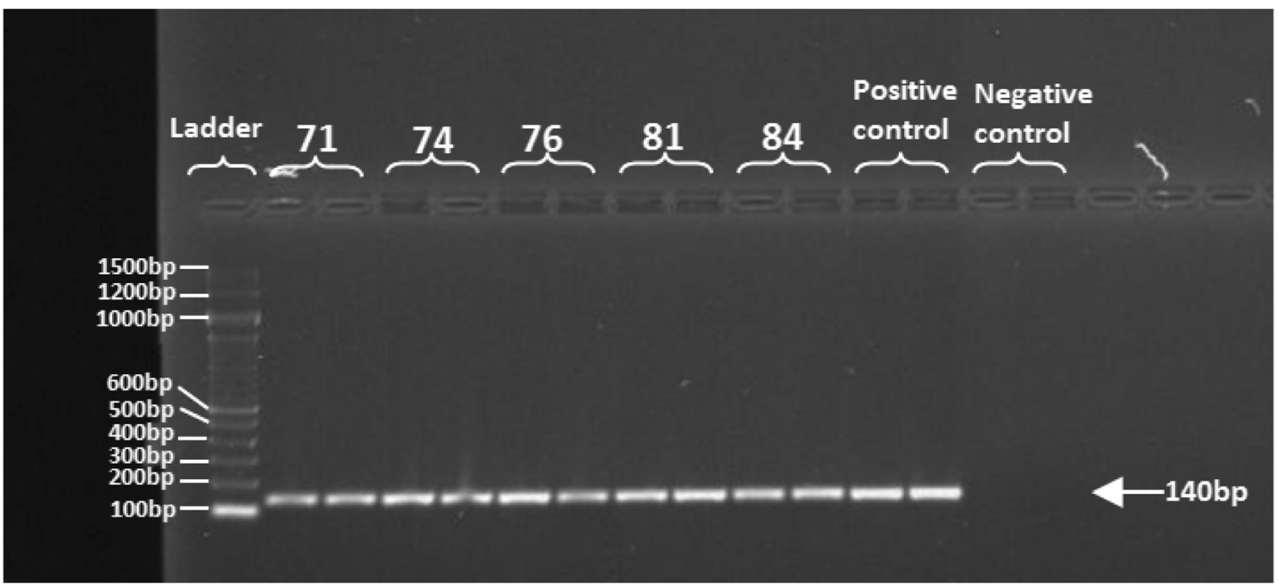




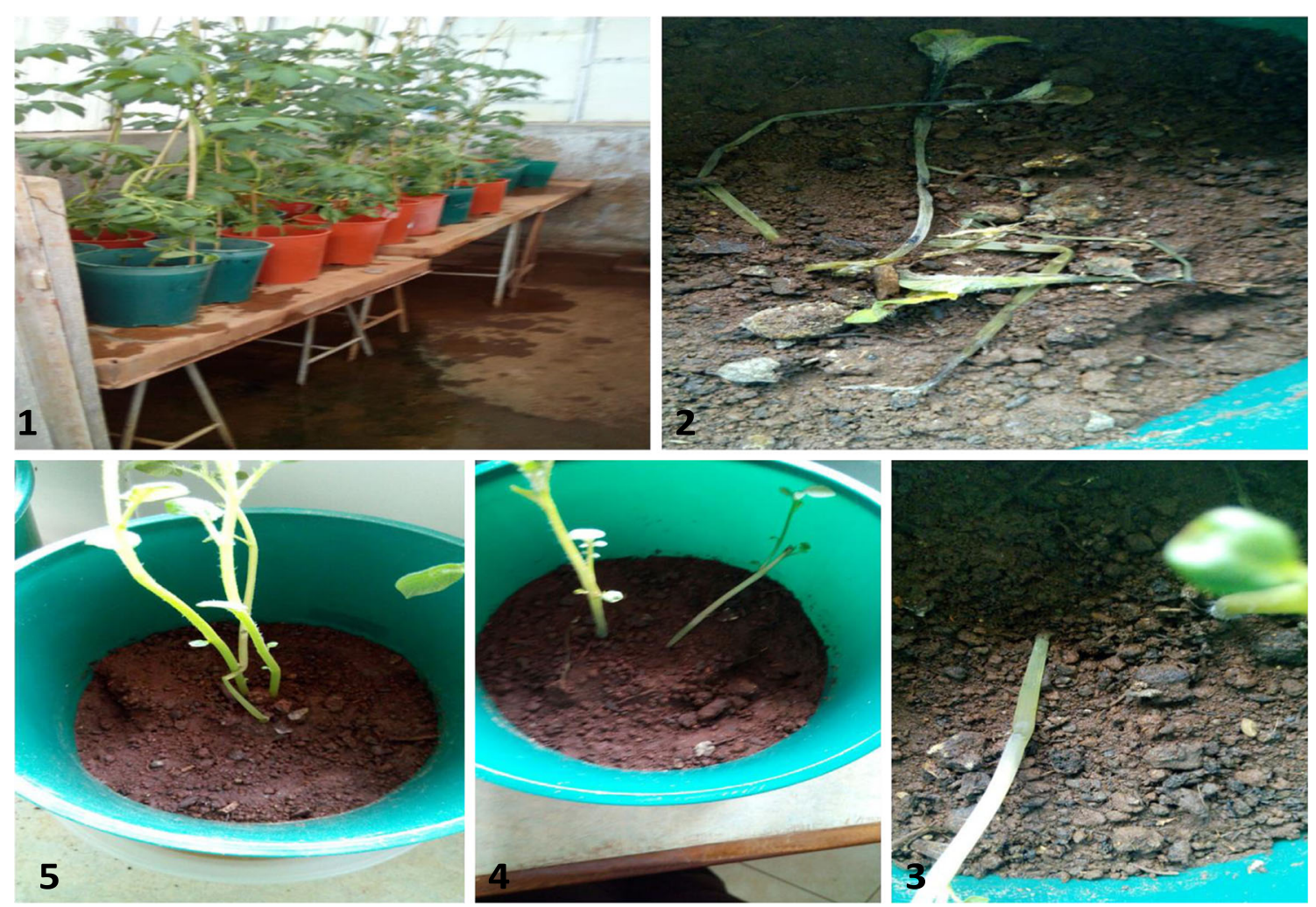

Fig. 4 Pot trials. 1, uninfected plants serving as the negative controls; the plants remained healthy for the entire 90 days. 2 , seed tuber infected with positive control PD 1006; the plant died within 21 days. 3, 4, 5, seed tubers infected with pure culture colonies from Elgeiyo Marakwet.; the plants showed soft rot and black rot symptoms from the base upwards within 21 days
Pectobacterium and 12 isolates were indole positive, indicative to the genus Dickeya although Pectobacterium carotovorum subsp. brasiliense strains may also be indole positive (Lee et al. 2014). According to Dickey (1978), pectinolytic bacteria are oxidase negative because they lack cytochrome oxidase enzyme that catalyzes transport of electrons between donors in the bacteria and a redox dye-tetra-metthyl-p-phenelyne-diamine to produce purple color, but may vary on indole and other tests. Most Pectobacterium spp. and strains are indole negative. They lack the enzyme tryptophanase which decomposes the amino acid tryptophan to indole. Dickeya spp. and some P.c. subsp. brasiliense strains are indole positive because they contain the enzyme tryptophanase (Ma et al. 2007; Lee and Yu 2006; Lee et al. 2014). The 26 isolates that were positive on slice rot tests (Fig. 5) including the 12 which showed blackleg and stem rot symptoms (Fig. 4) were subjected to conventional PCR for further identification. Six isolates (23\%) successfully amplified with the EXPCCF/EXPCCR primer pair to produce the expected 550 bp amplicon of P.c. subsp. carotovorum while five (19\%) amplified with PW7011F/PW7011R primers to produce the expected amplicon of 140 bp for P.c. subsp. wasabiae (see Fig. 3). However, we could not confirm by using the available primer set the group of 12 isolates which were indole positive as potential Dickeya spp. (E. chrysanthemi) or Pectobacterium carotovorum
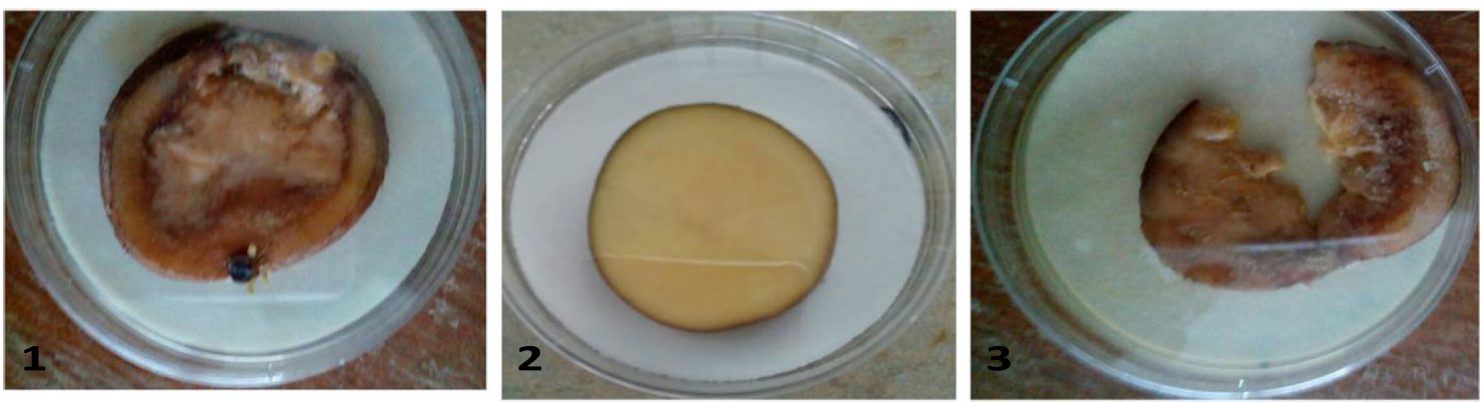

Fig. 5 Slice rots trials. 1, seed tuber infected with a pure culture colony from the Elgeiyo market samples. 2, healthy seed tuber used as the negative control. 3, infected seed tuber with Pcc positive control strain number PD 1006. Rotting was observed within $72 \mathrm{~h}$ 
subsp. brasiliense. Conventional PCR was ran for this group of isolates using Dickeya generic primer set ADE1 / ADE2 and BRIf /LIr specific for Pectobacterium carotovorum subsp. brasiliense (Pritchard et al. 2012). Apart from the positive control (Dickeya dianthicola strain GBBC 322), none of the isolates in this group gave the expected product size of 420 bp for Dickeya spp., instead, the isolates produced bands between 1000 and $1500 \mathrm{bp}$. On the test for Pectobacterium carotovorum subsp. brasiliense all the twelve isolates were negative too. Reisolation of the pathogens from the host plants and potato slices which had turned positive for $P$. carotovorum and $P$. wasabiae was done to identify the specific causative agent of blackleg and soft rot disease in these potato samples. All the reisolated bacteria were tested by conventional PCR as described by Pritchard et al. (2012) and biochemical tests as described by Perombelon (2002). The six samples which had previously turned positive for $P$. carotovorum remained positive for this test while the five which had turned positive for $P$. wasabiae remained positive too for this test. These isolates were also positive on $\mathrm{O} / \mathrm{F}$ tests but negative on indole tests, and oxidase tests. The combined results of phenotypic and DNA based tests show that indole positive pectinolytic bacteria are present in Kenya, but their identity has to be further investigated. The results of our study are in line with the results of Onkendi et al. (2014) that Pectobacterium carotovorum subsp. carotovorum is the main pathogen found in blackleg and soft rot affected potatoes in Kenya. This bacterial disease is estimated to account for as much as $1 / 4$ of the annual potato losses (Onkendi et al. 2014). Our study by the phenotypic results (indole test) may indicate that virulent pectinolytic bacteria are prevalent and probably may not be part of the genus Pectobacterium. It must be stated, however, that some strains of P.c. subsp. brasiliense are also indole positive (Lee et al. 2014), necessitating further study of these isolates (Figs. 4 and 5).

In conclusion, our study identified Pectobacterium carotovorum subsp. carotovorum as the main cause for blackleg and soft rot of potato. This pathogen as well as P. carotovorum subsp. brasiliense are known to occur in Kenya (Onkendi et al. 2014). We were also able to discover for the first time P. carotovorum subsp. wasabiae causing potato blackleg and soft rot symptoms in Kenya. P. carotovorum subsp. carotovorum was found in all the four regions while P. carotovorum subsp. wasabiae was found only in Elgeiyo Marakwet. Indole positive, pectinolytic strains were found in all the four regions, their exact identity needs further study as well as their survival and virulence mechanisms. Moreover, sequence analysis of pel genes as housekeeping genes (Darrasse et al. 1994) should be done to finalize and confirm identifications.
Acknowledgements This research was supported by Kenya Plant Health Inspectorate Service.

Special thanks to Food and agriculture organization (FAO) for facilitating sample collection.

Open Access This article is distributed under the terms of the Creative Commons Attribution 4.0 International License (http:// creativecommons.org/licenses/by/4.0/), which permits unrestricted use, distribution, and reproduction in any medium, provided you give appropriate credit to the original author(s) and the source, provide a link to the Creative Commons license, and indicate if changes were made.

Publisher's Note Springer Nature remains neutral with regard to jurisdictional claims in published maps and institutional affiliations.

\section{References}

Czajkowski R, Pérombelon MCM, Jafra S, Lojkowska E, Potrykus M, Wolf JM, Sledz W (2015) Detection, identification and differentiation of Pectobacterium and Dickeya species causing potato blackleg and tuber soft rot. A review. Ann Appl Biol:18-38. https://doi.org/ 10.1111/aab.12166

Darrasse A, Priou S, Kotoujansky A, Bertheau Y (1994) PCR and restriction fragment length polymorphism of a pel gene as a tool to identify Erwinia carotovora in relation to potato diseases. Appl Environ Microbiol 60:1437-1443

Dickey RS (1979) Erwinia chrysanthemi: a comparative study of phenotypic properties of strains from several hosts and other Erwinia species. Phytopathology 69: 324-329

Helias V, Hamon P, Huchet E, Wolf JVD, Andrivon D (2012) Two new effective semiselective crystal violet pectate media for isolation of Pectobacterium and Dickeya. J Plant Pathol:339-345. https://doi.org/ 10.1111/j.1365-3059.2011.02508.x

Ismail ME, Mostafa YM (2012) Identification and pathogenicity of phytopathogenic bacteria associated with soft rot disease of girasole tuber in Egypt. J Bacteriology Research 4:1-8. https://doi.org/10. 5897/JBR11.015

Kim MH, Cho MS, Kim BK, Choi HJ, Hahn JH, Kim C, Kang MJ, Kim SH, Park DS (2012) Quantitative real-time polymerase chain reaction assay for detection of Pectobacterium wasabiae using YD repeat protein gene-based primers. J Plant Disease 96:253-257

Lee YA, Yu CP (2006) A differential medium for the isolation and rapid identification of a plant soft rot pathogen, Erwinia chrysanthemi. J Microbiol Methods 10:200-206

Lee DH, Kim JB, Lim JA, Han SW, Heu S (2014) Genetic diversity of Pectobacterium carotovorum subsp. brasiliensis isolated in Korea. J Plant Pathology 30:117-124

Ma B, Hibbing ME, Kim HS, Reedy RM, Yedidia I, Breuer J, Glasner DJ, Perna NT, Kelman A, Charkowski AO (2007) Host range and molecular phylogenies of the soft rot Enterobacterial genera Pectobacterium and Dickeya. J Phytopathol 97:1150-1163. https:// doi.org/10.1094/phyto-97-9-1150

Naggash T, Hameed S, Imran A, Hanif M K, Majeed A, Elsas V J D (2016) Differential response of potato toward inoculation with taxonomically diverse plant growth promoting rhizobacteria. Front Plant Sci 7:1-12. https://doi.org/10.3389/fpls.2016.00144

Onkendi EM, Maluleke LN, Moleleki L N (2014) First report of Pectobacterium carotovorum subsp. brasiliense causing soft rot and blackleg of potatoes in Kenya. J Plant Disease

Perombelon MCM (2002) Potato diseases caused by soft rot erwinias: an overview of pathogenesis. Plant Pathol 51:1-12

Pritchard L, Humphris S, Saddler GS, Parkinson NM, Bertrand V, Elphinstone JG, Toth IK (2012) Detection of phytopathogens of 
the genus Dickeya using a PCR primer prediction pipeline for draft bacterial genome sequences. Plant Pathol. https://doi.org/10.1111/j. 1365-3059.2012.02678.x

Rahman MM, Ali ME, Khan AA, Hashim U, Akanda AM, Hakim MA (2012) Characterization and identification of soft rot bacterial pathogens in Bangladeshi potatoes. J Microbiol Res 6:1437-1445
Rosenzweig N, Steere L, Hammerschmidt R, Kirk W (2016) Tuber soft rot, blackleg and aerial stem rot. Extension Bulletin E3335. 1-4 Sambrook J, Russell DW (2001) Molecular cloning:a laboratory manual, vol 2, 3rd edn.Cold Spring Harbor Laboratory Press, New York

Wang'ombe J, Dijk M (2013) Low potato yields in Kenya. Do conventional input innovations account for the yields disparity?. Agriculture and Food Security 14:2-14. https://doi.org/10.1186/2048-7010-2-14 